\section{Multidisciplinary SCIENTIFIC JOURNAL OF MARITIME RESEARCH}

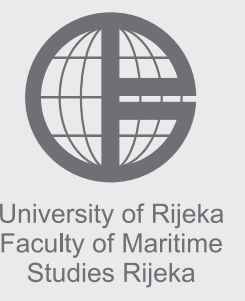

Multidisciplinarni znanstveni časopis POMORSTVO

\title{
Maritime environmental security
}

\author{
Dario Matika, Slavko Barić \\ Croatian Military Academy “Dr. Franjo Tuđman”, Ilica 256b, 10000 Zagreb, Croatia, e-mail: dario.matika1@gmail.com; sbaric957@gmail.com
}

\section{ARTICLE INFO}

Review article

Received 23 March 2016

Accepted 30 May 2016

Key words:

Security

Marine environment

Mapping

Autonomous Underwater Vehicles

\section{Introduction}

Making sea free of dangerous objects is determined by new technologies of detection, identification, neutralization and demining of dangerous objects dumped, piled up or left behind following warfare and other activities on the Adriatic Sea. Due to years of impact of external environment, sedimentation and overgrowing these dangerous objects are hard to detect and recognize and it is difficult to make conclusions about their stability or disintegration upon which the measures to be taken depend. Wrong approach and demining measures can furthermore contaminate and pollute the location. Such state of affairs is present not only in the Adriatic Sea but in the Mediterranean and other seas as well. In order for the activities to be undertaken with quality, effectively and economically a necessary precondition is to master latest technologies and equipment which would map and georeferenced underwater situation of the location in the GIS system - the aim is to create marine cadastre and maritime demesne cadastre serving investors in making investment studies and starting economy activities and tourism. Furthermore, detection and location screening is necessary in order to set appropriate measures and procedures for humanitarian demining and location clearance from objects dangerous to humans and environment, after which the measures would be carried out, and certificates and guarantees issued. The dem- ining of the underwater environment, especially of the seas and rivers where vessel traffic is underway, accompanied with economic and tourism activities, plays important role in global security and international relations. This results in new security dimensions (social, economy, energy, ecology etc.), while the environmental security concept (marine included) becomes the element of national security and international relations.

\section{Maritime environment}

Marine environment degradation and non-demining, that is, non-removal of dangerous objects from seas and oceans poses threat to human health, resources availability and normal functioning of ecosystems. The UN Environment Program (United Nations Environment Program - UNEP (DEPI)/MED WG. 334/Inf. 922 May 2009) reveals the level of pollution of the Adriatic Sea. The following images show munitions dumpsites in the Adriatic Sea, Figure 1 and 2.

The Figure 2 shows in more detail the dumpsites in the Strait of Otranto of the Adriatic Sea.

Ocean currents can contribute to the increase of concentration of explosive components and heavy metals in the environment. A typical situation at a brownfield location contaminated with dumped munitions and mine and explosive ordnance is presented in the Figure 3. Marine 


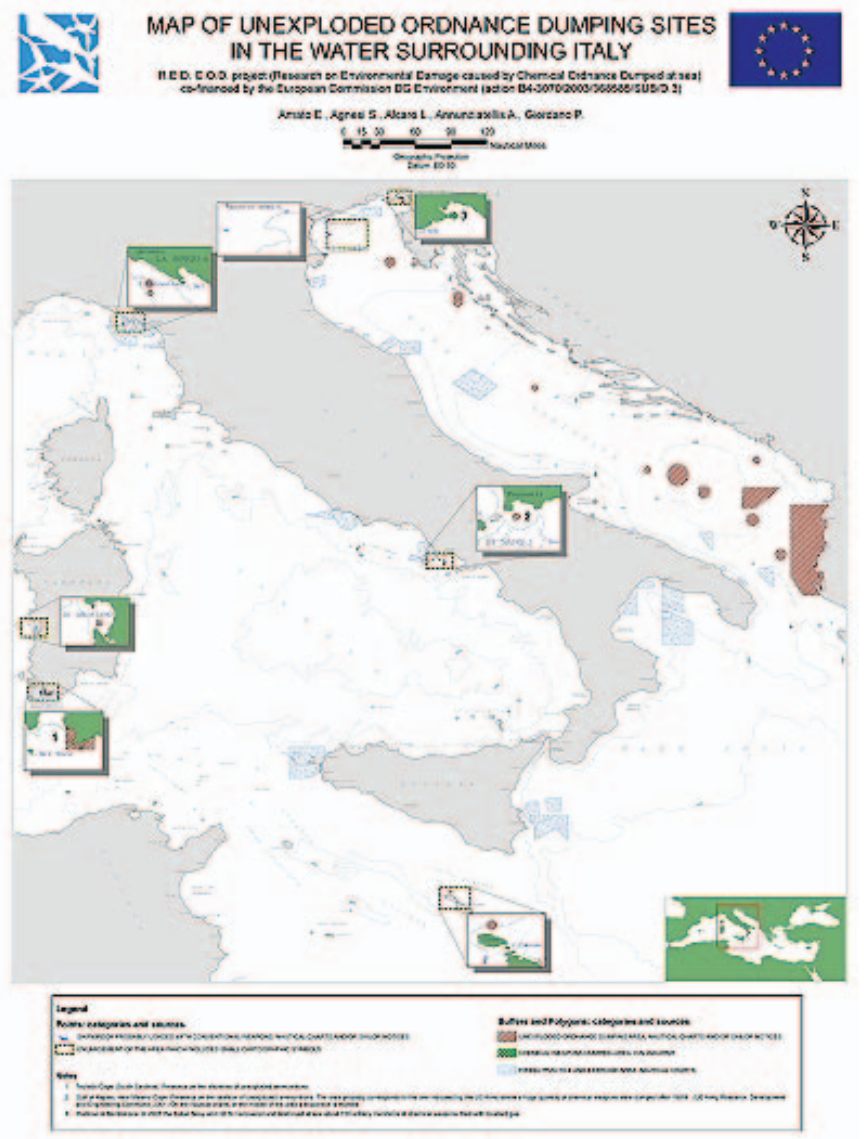

Figure 1 Munitions dumpsites in the Adriatic Sea

Source: UNEP

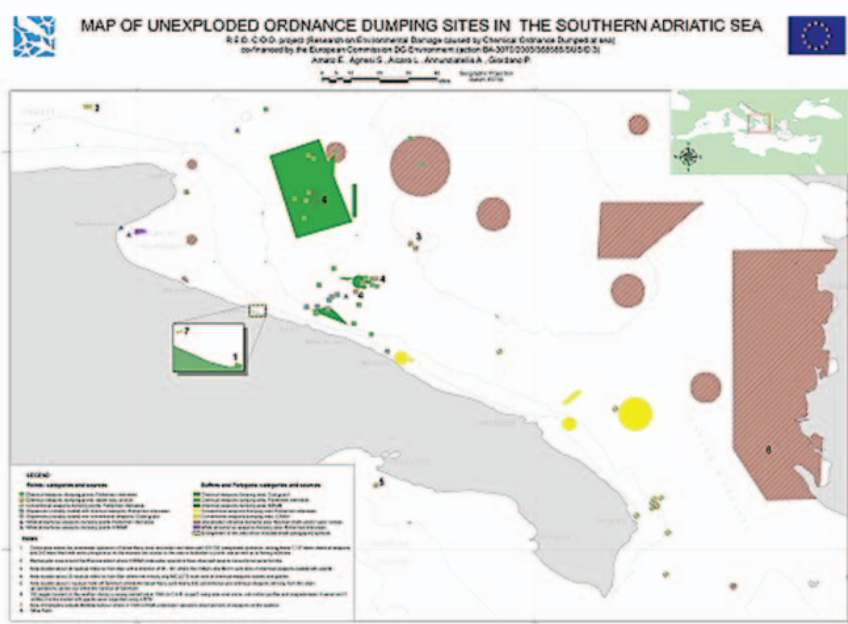

Figure 2 Munitions dumpsites in the Adriatic Sea

Source: UNEP

environment affects dumped ordnance resulting in seawater contamination due to the dissolving of ordnance and heavy metals corroding in sea-water.

In world seas, thus in the Adriatic as well, there are a number of munitions and mine and explosive dumpsites. Military disposal sites are locations designated by the military authorities for marine waste disposal, while as the objects could be regarded various waste with military purpose or that was used for military purposes disposed on the seafloor. Military dumpsites can be categorized in three groups: ordnance, chemical weapons and radioactive

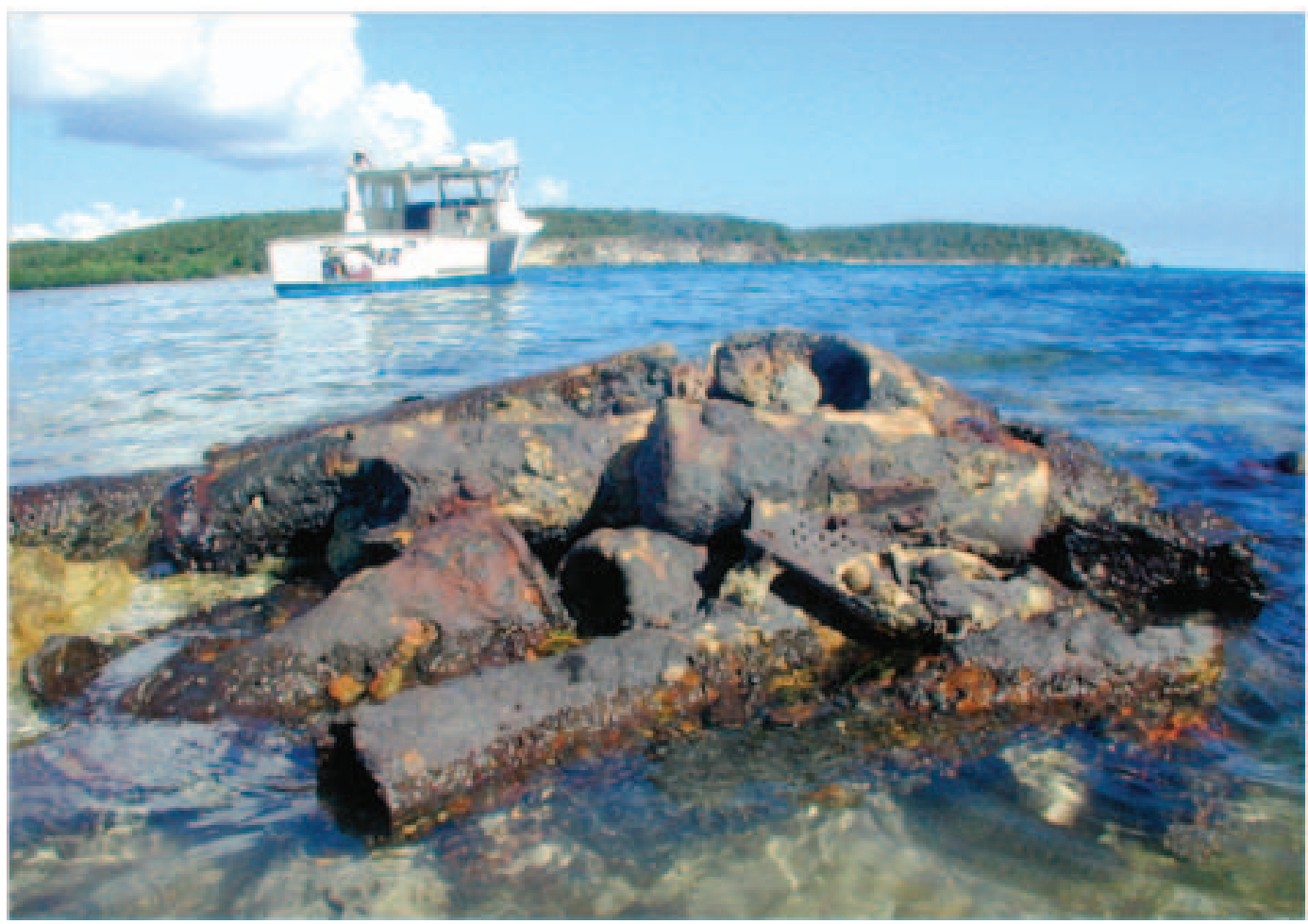

Figure 3 Sea-water contamination (dumped munitions) 


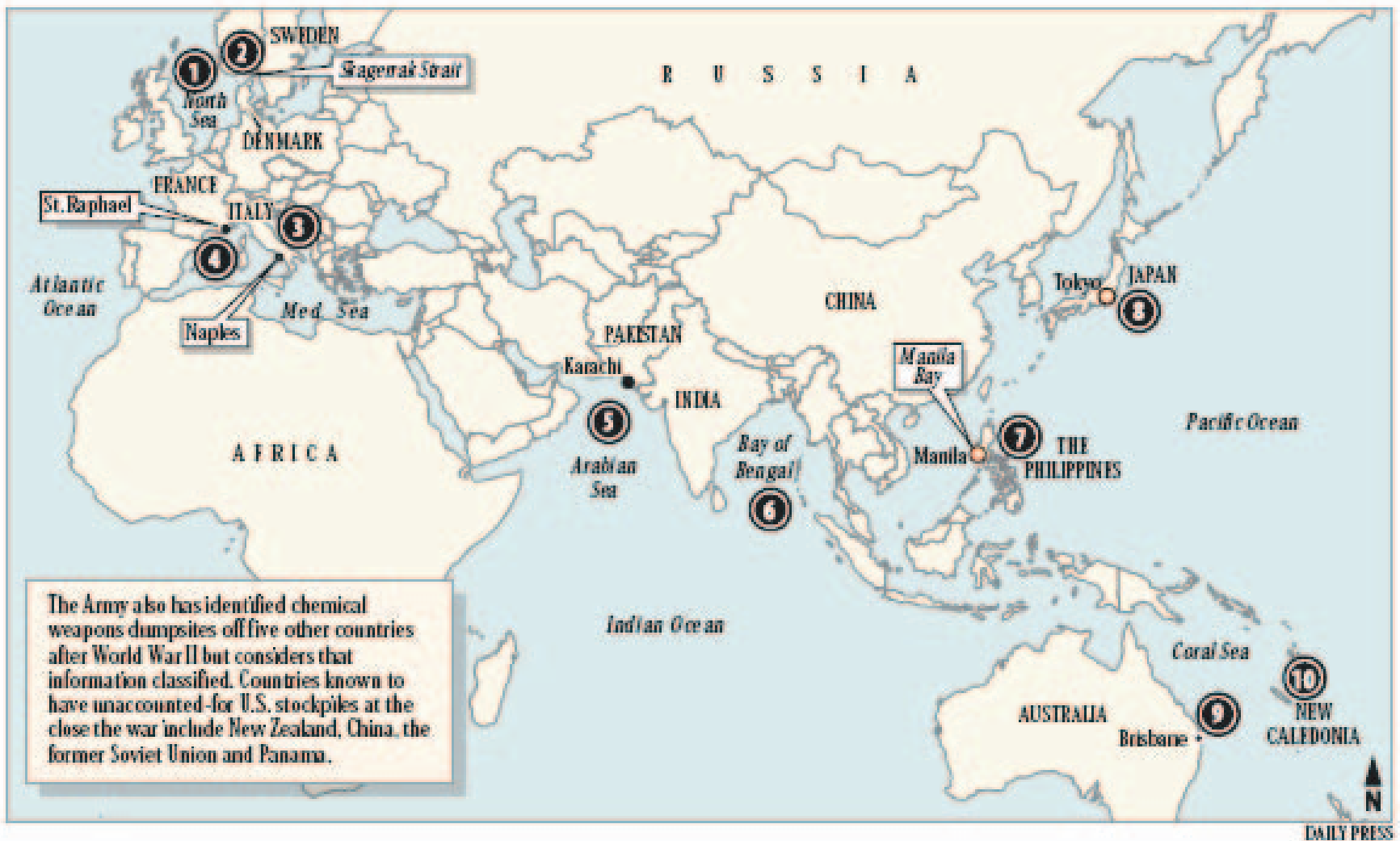

Figure 4 Chemical weapons dumped locations

Source: Valković V., AC\&T

waste dumpsites. All three categories classify under hazardous waste. Research have shown that majority of material used for the making of the aforementioned objects can be extremely toxic to marine organisms. This group of dangerous locations includes weapons testing sites. Dangerous disposed object, chemical weapons in particular, carries the following risk for human health: the impact on health due to direct physical contact, impact on marine organisms and environment in immediate vicinity of the dumpsite, consuming contaminated marine organisms, and explosions that can occur spontaneously or during the relocation. In favor of need to build sustainable capabilities of detecting, identifying and humanitarian demining of dangerous objects speaks the fact that the Adriatic Sea is home to locations contaminated with chemical weapons and ordnance. After the World War II the Allies dumped into the sea the majority of weapons, both their and captured. Some of key locations are illustrated in the Figure 4.

Key locations are: in the North Sea - The Phillip Heiniken cargo ship sunk with 2,000 tons of chemical weapons and 2,500 tons of unidentified chemical munitions dumped into the sea in 1948; Norway/Denmark - the Americans and the British dumped 170,000 tons of German nerve gas and other chemical weapons in sinking 33 ships in the strait that separates Norway and Denmark resulting in 150 fishermen being killed in Denmark; Italy and France - an estimated 300,000 tons of chemical warfare agents (CWA) was dumped into the seas surrounding Europe.
The most polluted locations contaminated with chemical weapons and ordnance in European seas are: Beaufort's Dyke (the sea trench between Northern Ireland and Scotland) - more than 1 million tons of munitions and about 14,500 tons of chemical munitions was dumped. The U.S. Liberty Ship SS John Harvey carrying 2,000 M47A1 mustard gas bombs, each of which held 30$35 \mathrm{~kg}$ of sulfur mustard and unknown quantity of "high explosives", was at the port of Bari during German bombing of the city on 2 December 1943. In the evening that day the ship was destroyed and sunk in a huge explosion at the port of Bari killing all the crew. The explosion of sulfur mustard caused a total of 630 military victims hospitalized and over 1,000 civilians being killed. Soon, following the end of World War II, the Americans dumped the unknown quantity of various chemical weapons, as described in their report "Off the Island of Ischia, near Bari". The dumps were done over the following periods: 12 Sep-5 Nov 1945; 1 Dec-15 Dec 1945 and 1 Apr-23 Apr 1946. In the period from 1946 to 1997 the researchers and doctors of the Bari University ${ }^{1}$ detected over 230 cases of exposure to sulfur mustard in the Adriatic Sea, largely among fishermen. The area marked red in the Figure 5 shows the location where the unknown quantity of chemical weapons was dumped.

\footnotetext{
Dr Sivo and Dr Lobuono, University of Bari continue with the work and publishing their research results
} 


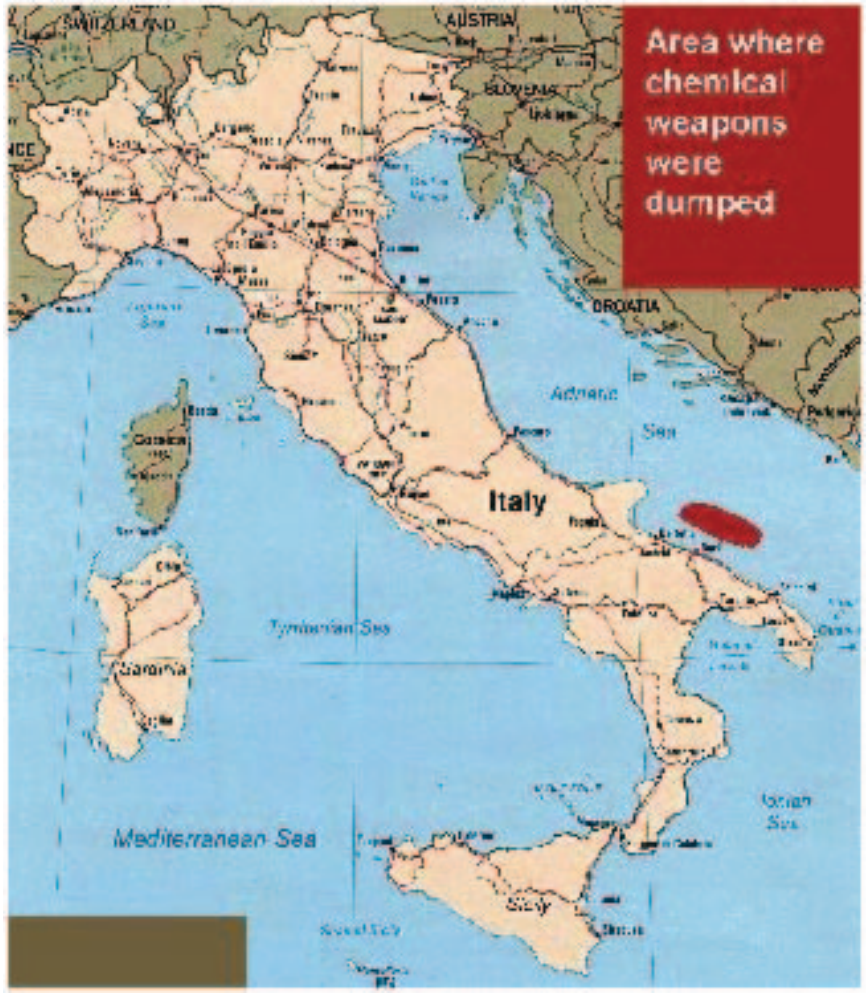

Figure 5 Location where the unknown quantity of chemical weapons was dumped
Today, two GIS databases of WWII shipwrecks are operational: Pacific Regional Environmental Programme (SPREP) and Atlantic - Mediterranean - Indian Ocean (AMIO).

- Pacific Regional Environmental Programme (SPREP) was realized as a data compilation project of all vessels sunken during World War II in the Asia/Pacific region. The GIS database contains data on: ship type, tonnage and location of more than 3,800 vessels (including 330 tankers and oilers) lost in World War II.

- Atlantic - Mediterranean - Indian Ocean (AMIO) is still in its initial development and details data and location of over 3,950 vessels over 1,000 tons, of which 529 are oil tankers.

Current estimates indicate over 300,000 tons of chemical warfare agents in the waters around Europe. Most of the material was used for ammunition production, including chemical agents and explosives. Not only do they endanger human life, but are extremely toxic to marine organisms.

\section{Underwater environment mapping and the latest underwater technology}

Starting point for making a bathymetric chart of underwater environment is the area selection. In the selected area the analysis of the information content of maritime

Source: Valković V., AC\&T

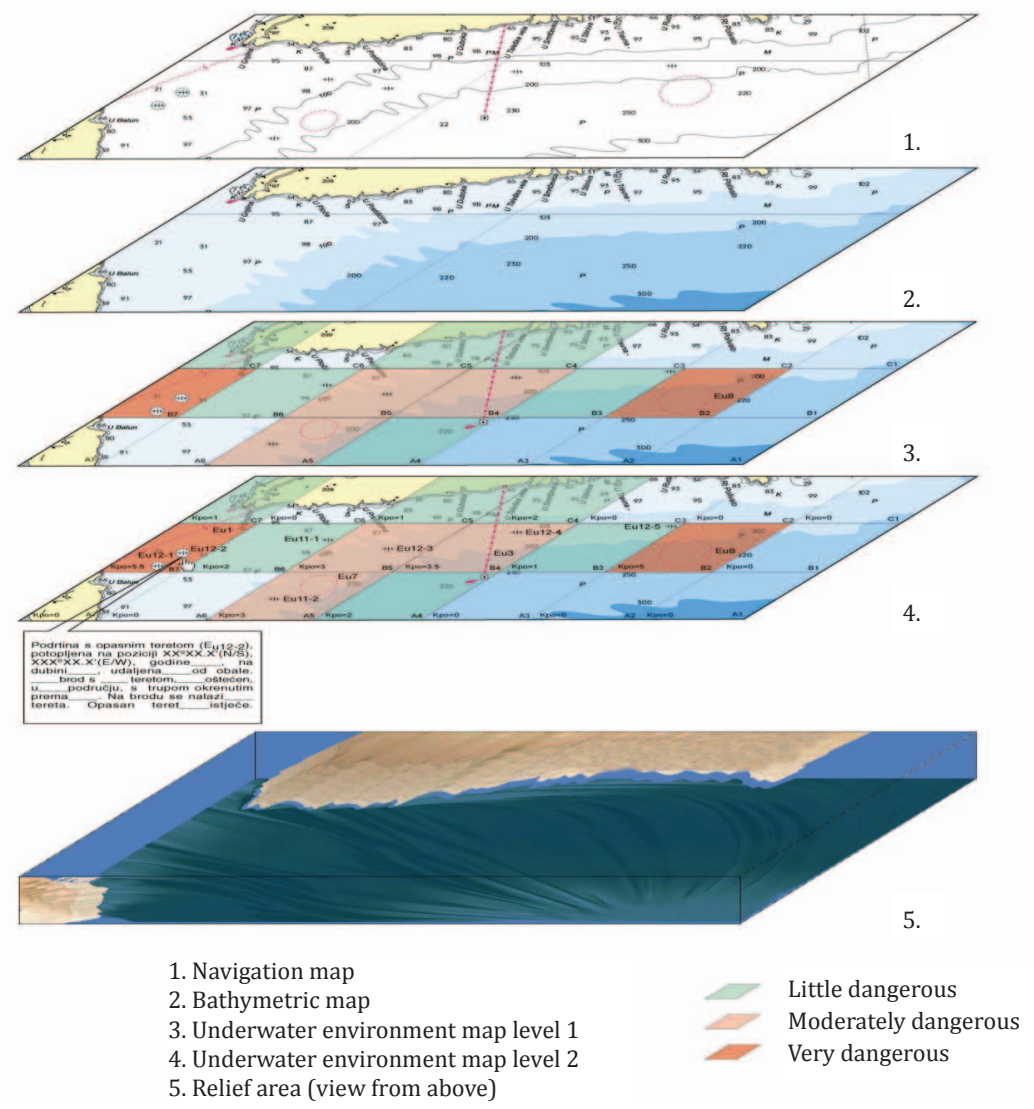

Figure 6 Mapping of dangerous objects in underwater environment 
navigation and bathymetric charts is performed. Once the analysis confirms the existence of unknown objects on the seafloor, the data collection is undertaken and if the object's condition analysis confirms its hazardous status the process of mapping dangerous objects of underwater environment begins. The results of such process are underwater environment bathymetric charts describing the objects and the level of hazard as shown in Figure 6.
New underwater technology utilized for underwater mapping is the Underwater Autonomous Vehicle (AUV). The Figure 7 shows REMUS type AUV structure.

The AUV autonomously explores a designated area at the speed of 3 to 4 knots hovering 3 to 20 meters above the seafloor. The designated area is shown in the Figure 8 and the exploration results in Figure 9.

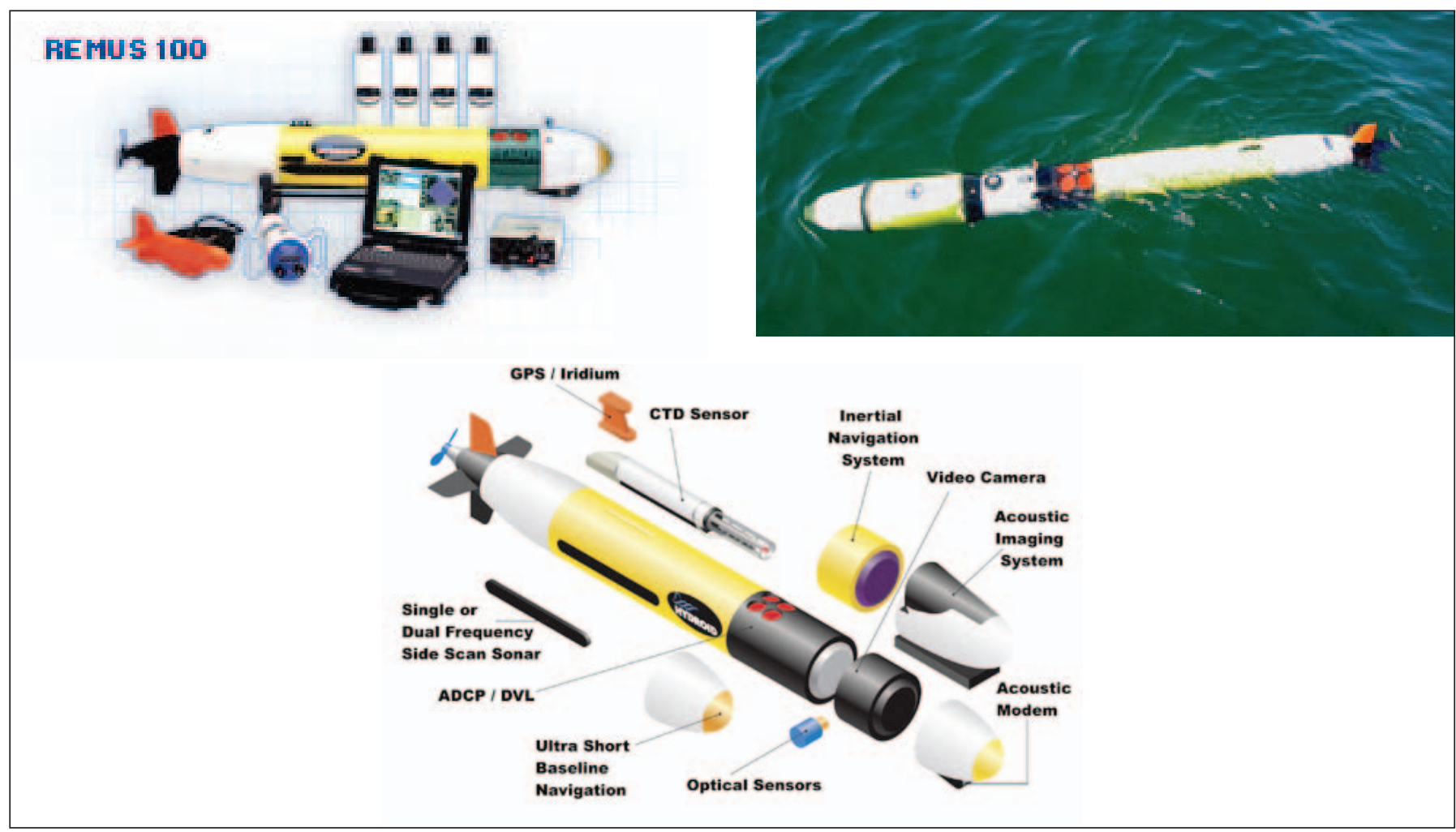

Figure 7 REMUS type AUV

Source: Manufacturer's Catalogue

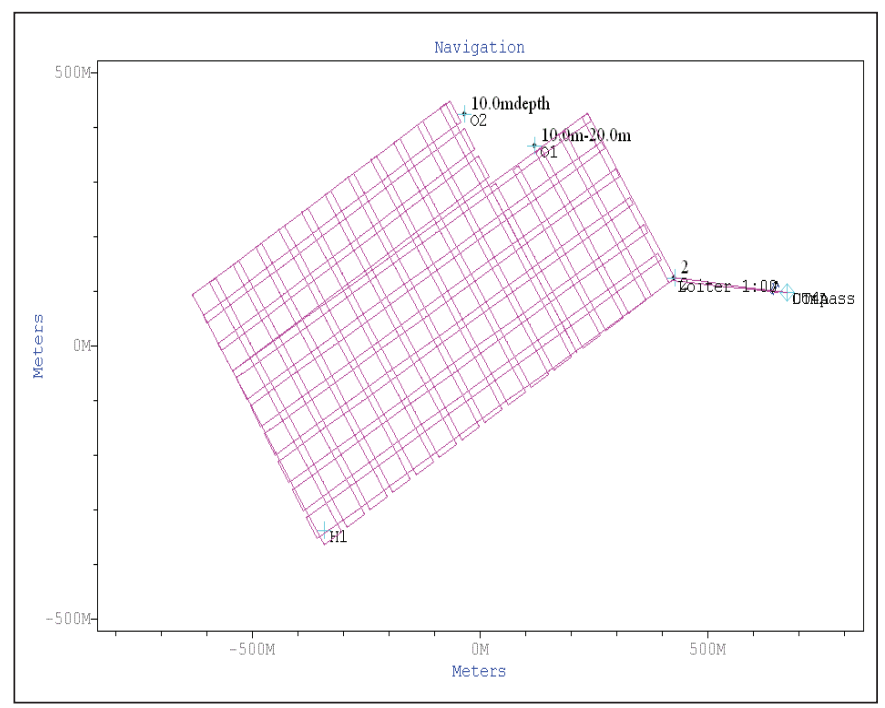

Figure 8 Designated area of exploration

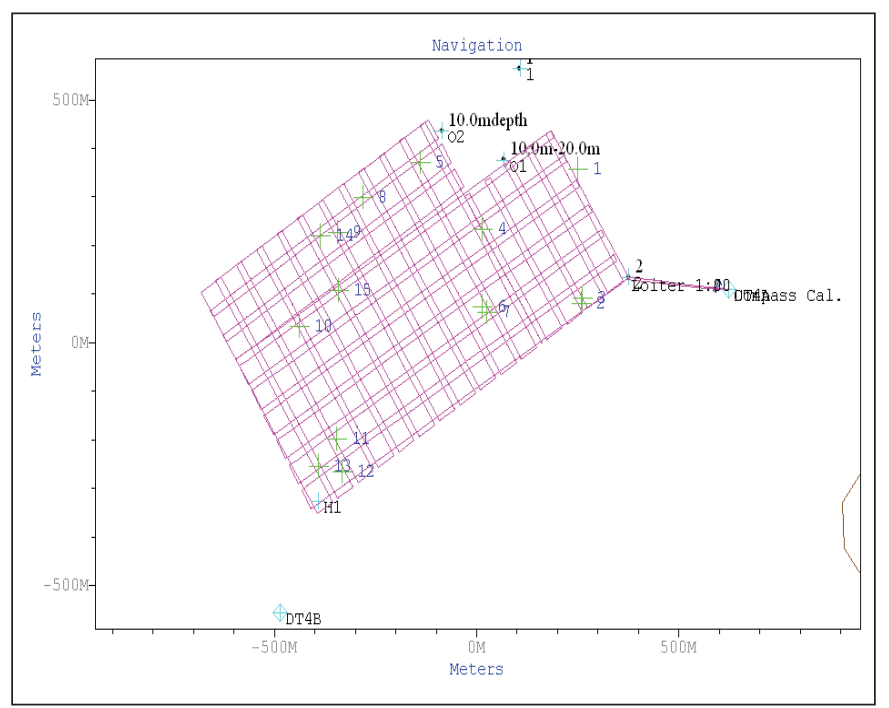

Figure 9 Exploration results 


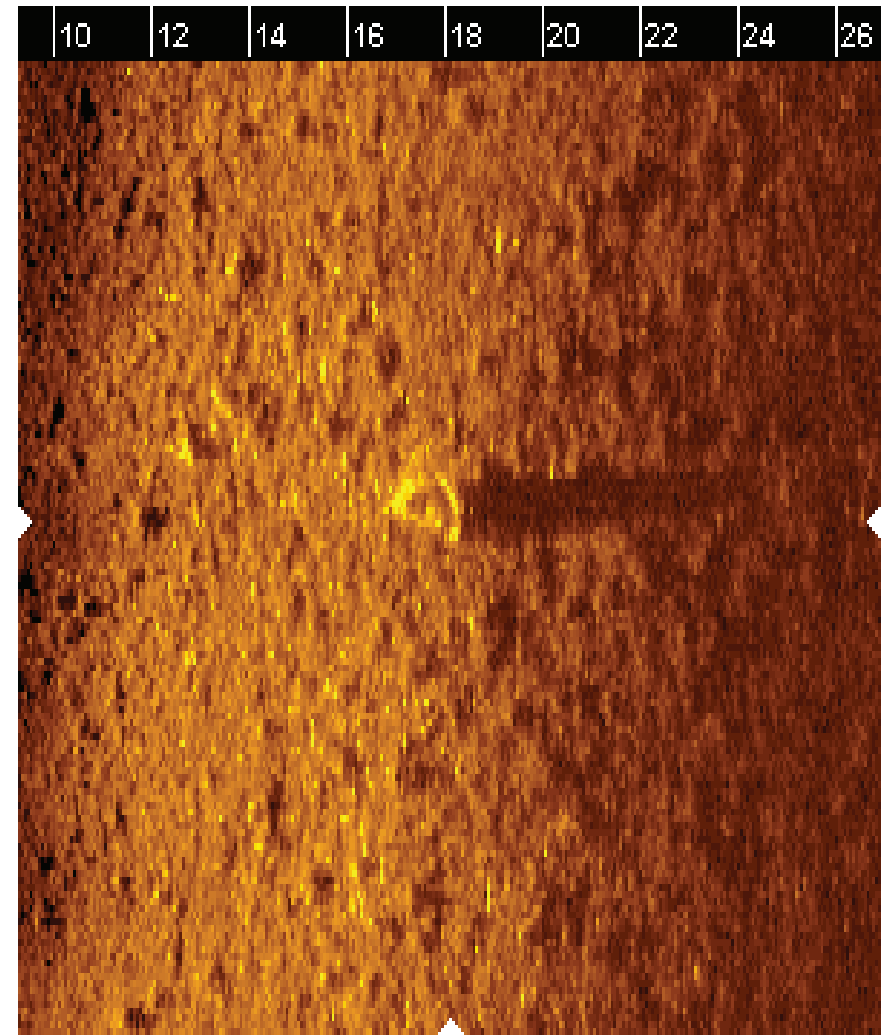

Metal Object

Position: 43N31.740 16E24.338

Source file: REMUS073.MST

Map position: 8

Figure 10 Identification of unknown object

Source: Vukić Z., FER
Spots marked in the exploration area, which is explored on horizontal and vertical axis, present potential locations where "unknown objects" are situated. This is followed by an additional analysis shown in the Figure 10 and the identification of the unknown object.

In this concrete example it is about a metal object on the seafloor - possibly a dumped naval mine or a container with unknown contents. Mapping-wise, it is necessary to emphasize that the AUV recorded the precise geographical position of the unknown object. A new example of underwater AUV exploration is shown in the Figure 11 with the exploration area (in brown) and detection area - a naval mine identified, in other words. Coordinates and depth recorded are registered on digital charts - that is, a marine cadaster.

Apart from the detection and identification purposes of munitions, mine and explosive ordnance, naval mines, torpedoes, grenades, air-dropped bombs and similar ordnance, the AUVs can be utilized for other purposes shown in the following images - non-explosive objects mapping on the seafloor (Figure 12).

The Figure 13 shows the mark on the seafloor left after the sinking and extraction of the SMS Viribus Unitis which after the sabotage action (limpet mining) sunk in Pula, the military port at that time.
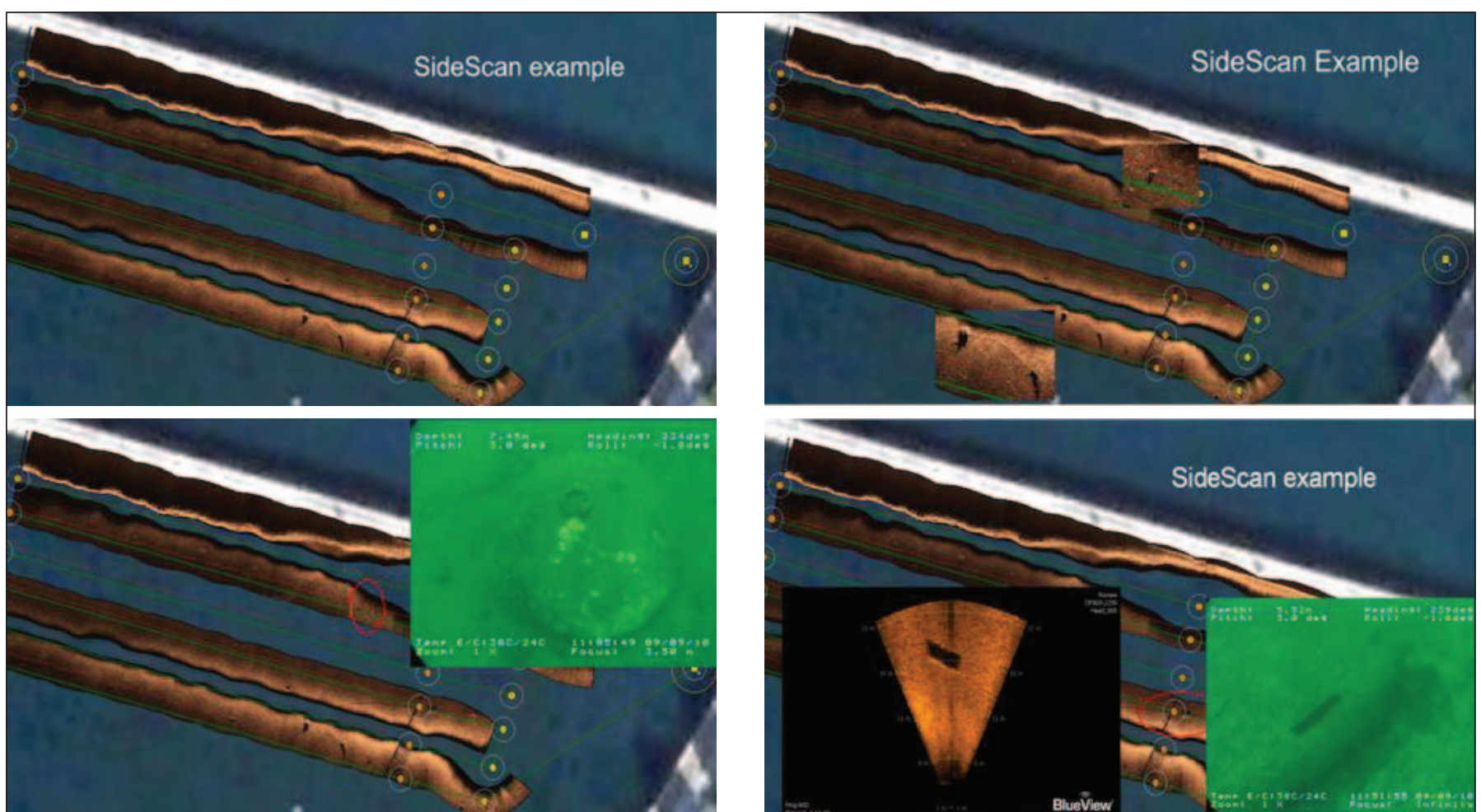

Figure 11 Underwater mine detection and identification 


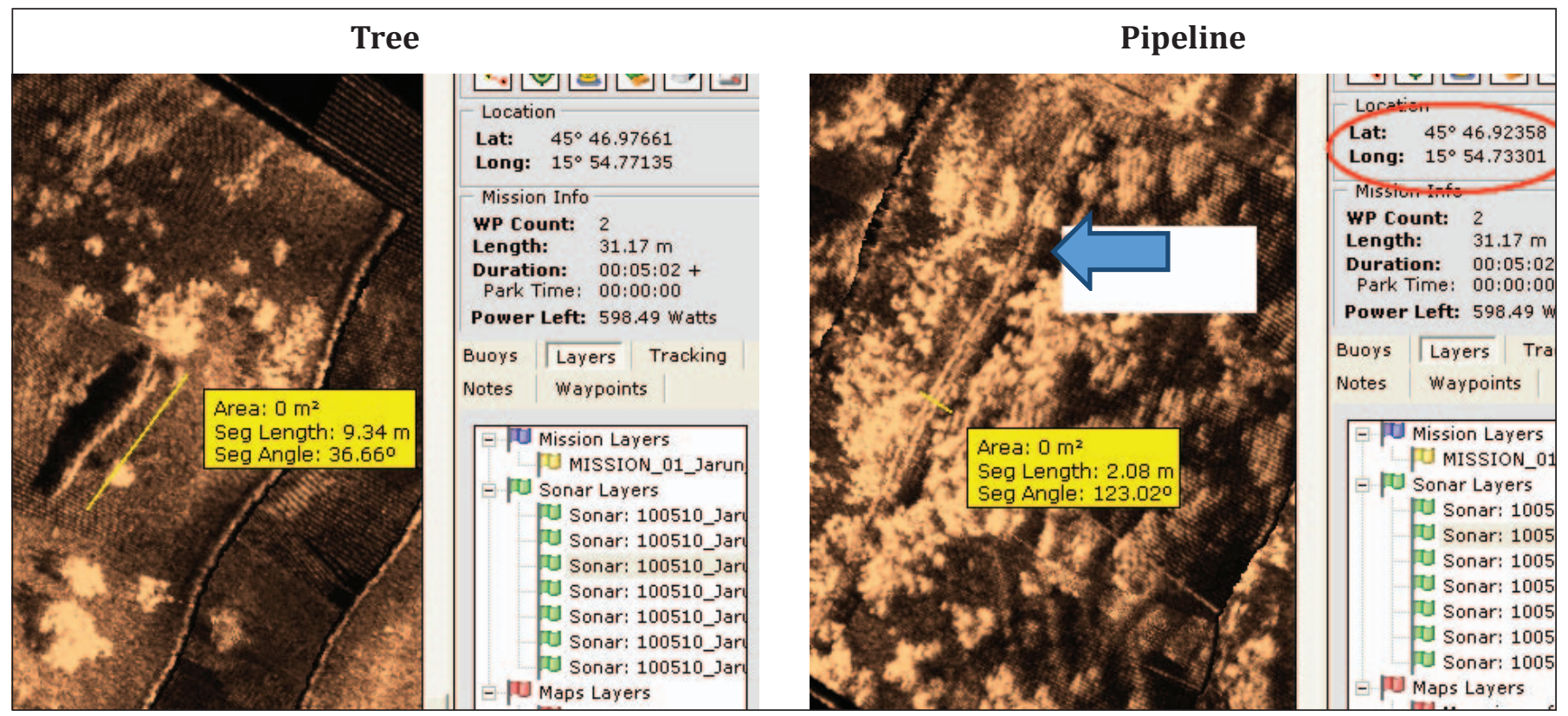

Figure 12 Non-explosive objects on the seafloor

Source: Vukić Z., FER

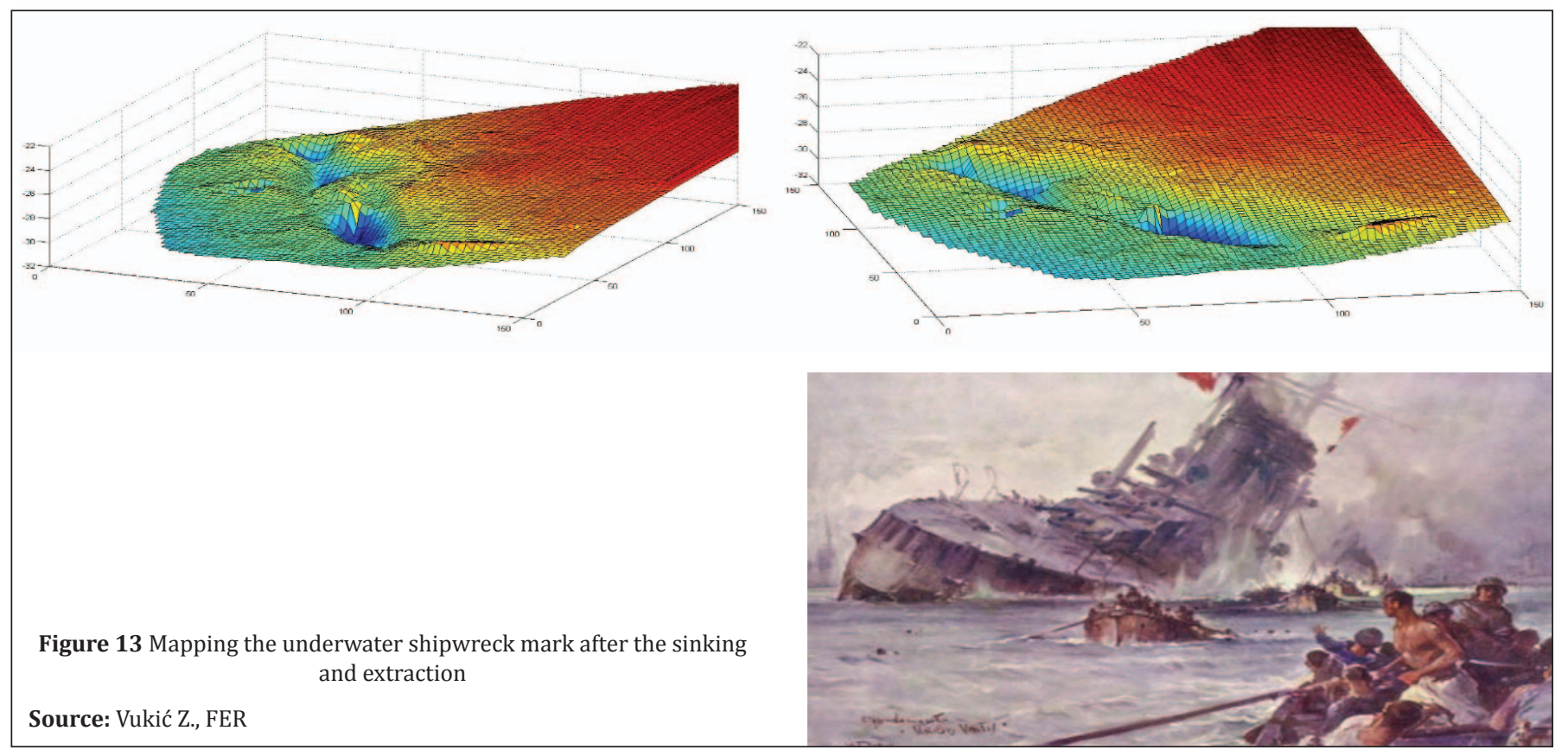

Apart from the mentioned data, new technologies installed in the AUVs can collect data on depths (bathymetry, in blue), temperatures (in red), chlorophyll (in green) and salinity (in grey). That data can be digitally charted. The area that the mentioned data was collected from, being at the same time the area that the AUV explored, is shown in the Figure 14.

As a NATO member Croatia took on certain commitments regarding the protection of collective security. In that respect, in the environmental security field, NATO lays emphasis on the remediation of contaminated mili- tary locations. Remediation is the process of taking measures for pollution stopping and further degradation of living environment up to the level of secure utilization of locations - including the reconstruction of area, its revitalization and recultivation. As part of this activity, the navies of NATO member countries carry out seafloor clearance and demining actions at the munitions and mine and explosive ordnance dumping sites, as well of their own ports and bases. In that respect, the remediation of contaminated areas from explosives, munitions and mine and explosive ordnance involves the following activities: cataloging, 

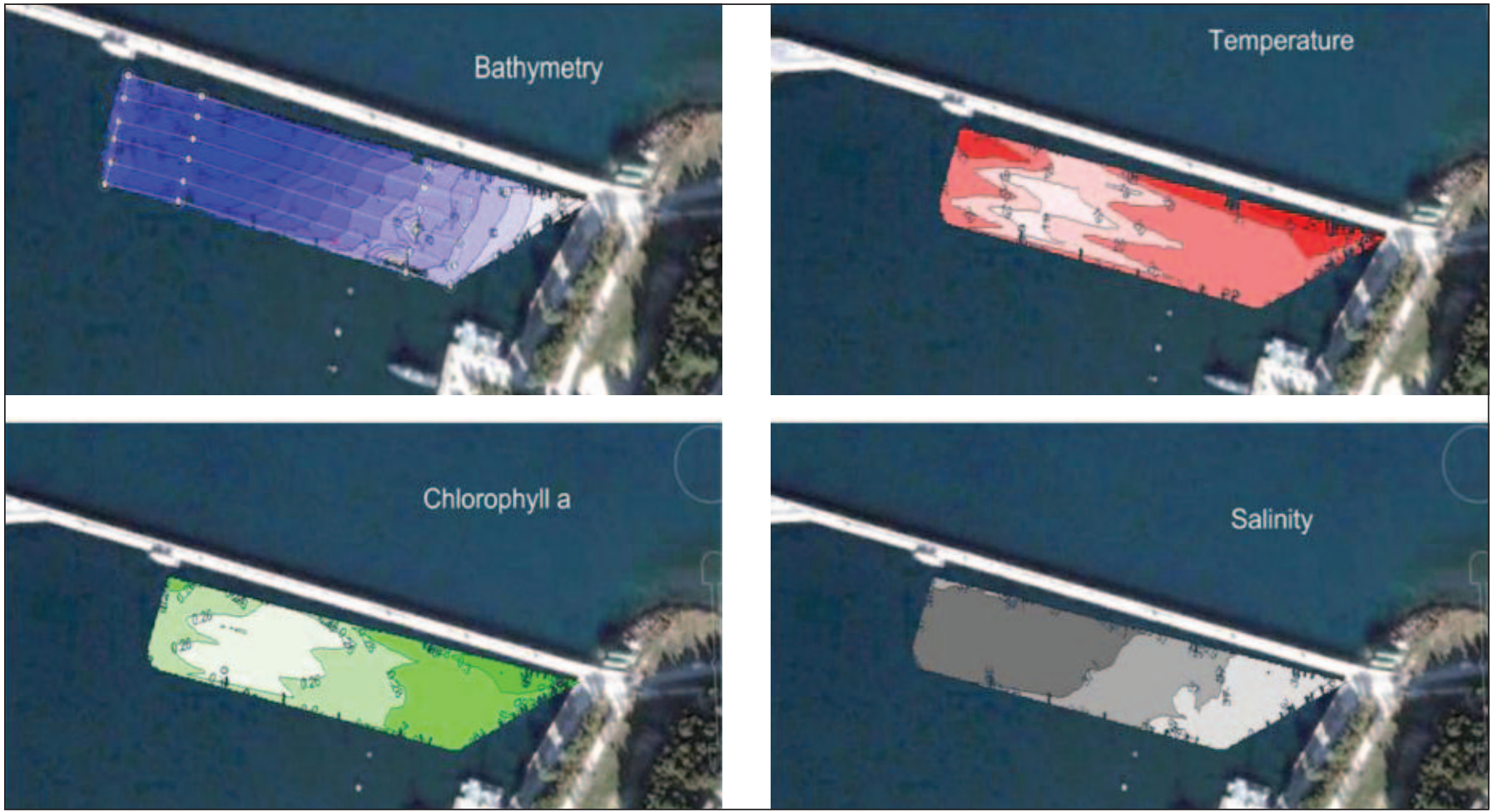

Figure 14 Collected data on depths (bathymetry, in blue), temperatures (in red), chlorophyll (in green) and salinity (in grey) in the AUV mission area

Source: Vukić Z., FER

describing and documenting suspected residual locations to be used in civil sector, previously utilized by the armed forces, and detecting the underwater environment condition of those sites with regard to ordnance dumped into the sea or left behind; mapping, preferably digitally, the underwater conditions of the site and assessing the risk; starting detecting and detailed screening of suspected underwater areas; taking demining measures eliminating hazard to humans and environment; issuing a certificate and guarantee confirming that the underwater area is cleared and hazard-free for human health and life.

\section{Conclusion}

Generally, the environmental security as a term appeared for the first time at the end of the last century, following the end of the Cold War, when the idea of security underwent its redefinition leading to a comprehensive approach in dealing with the upcoming security challenges. In order for the secure environment concept in the field of sea navigation, security of navigation and tourism to be viable, the so-called passive approach is not sufficient - the approach based on pollution assessment and environmental management only after a line of irreversible damage for the local environment takes place. Instead, a proactive approach oriented towards sustainable development principles and requiring action prior to damage to marine environment occurs is needed. All together, the detecting, mapping and humanitarian demining of underwater (marine) environment of the munitions and mine and explosive ordnance left behind or dumped, corroding and disintegrating on the seafloor and releasing substances dangerous and toxic to marine environment contribute to global security as well - preserving marine environment healthy is one of key elements of the present national and international security.

The challenge that not only Croatia stands before, but many other EU countries as well, is how to fix the marine environment degradation made in the $19^{\text {th }}$ and $20^{\text {th }}$ century, caused by deliberate or non-deliberate human action. Such measures, besides the detecting, mapping and humanitarian demining, include keeping marine environment healthy, being a component in securing clean and non-polluted waters. Preserving drinking water sources and marine waters is a security question par excellence for Croatia.

Furthermore, such approach is connected to the sustainable development principle, making the investment in the detecting, mapping dangerous objects and humanitarian underwater (marine) demining, an investment in future development of the Republic of Croatia.

\section{References}

[1] Barić - Punda V.: Uloga Europske unije u zaštiti i očuvanju Sredozemnog mora s osvrtom na neke pravne i strateške dokumente, Zbornik radova Pravnog fakulteta u Splitu, god. 45 (2008), br. 4 (90), 2008.

[2] Barić - Punda, V., Brkić, Z.: Zaštita i očuvanje Sredozemnog mora s posebnim osvrtom na obalne države članice Europske 
unije, Zbornik radova Pravnog fakulteta u Splitu, god. 44 (2007), br. 1, 2007.

[3] Bićanić Z., Kasum, J., Gržetić, Z.: Prilog unaprjeđenju postupaka za održavanje pomorskih karata i navigacijskih publikacija, Hrvatski geografski glasnik, Vol. 67, Br. 2, 2006.

[4] Duplančić Leder, T.: GIS u službi sigurnosti plovidbe, Drugi hrvatski kongres o katastru, Zbornik radova, Hrvatsko geodetsko društvo, Zagreb, 2001.

[5] Fraser, R., Todd, P. J. and Collier, P. A.: Issues in the Development of a Marine Cadastre. Addressing Difficult Issues in UNCLOS, 2003 ABLOS Conference, Monaco, 2003.

[6] Glasby, G. P.: Disposal of Chemical Weapons in the Baltic Sea, The Science of the Total Environment, 206, 1997.

[7] Hart, J.: A Review of Sea-Dumped Chemical Weapons, presented at 'The Environment and the Common Fisheries Policy, Threats to and Constraints on Sustainability', (Greenwich Forum), The Royal Society, 27 January 2000.

[8] Hecht, H.: The Digital Hydrographic Office - Challenges and Prospects of Hydrography in the evolving Geographic Information Infrastructure, BSH, Germany, 2003.

[9] Hoffsommer, J. C. and Rosen, J. M.: Analysis of Explosives in Sea Water, Bulletin of Environmental Contamination \& Toxicology, 7, 1972.

[10] Kasum, J.: Updating Sea Charts and Navigational Publications, The Journal of Navigation, Vol. 56, Cambridge University Press, 2003.

[11] Magron, F.: Bathymetric Mapping Using a Combination of Sonar Data and Satellite Imagery, SPC Fisheries Newsletter, No. 126 - July/September 2008.

[12] Matika D.: Invited Lecture "Pollution of the Adriatic Seabed" FP-7-REGPOT-projekt “CURE”, Grant agreement no. 229553, 2. International Interdisciplinary Lectures, Breaking the Surface 2010, Murter, Croatia, Section MARSEC.

[13] Monfils, R., Gilbert, T. \& Nawadra, S.: Sunken WWII Ship Wrecks of the Pacific and East Asian Region: The Need for Regional Collaboration to Address the Potential Marine Pollution Threat, Congress of the East Asian Seas, Kuala Lumpur, December 2003.

[14] Obhođaš, J., Valković, V., Sudac, D., Matika, D., Pavić, I.: Environmental security of the port and harbors' sediments, SPIE $5^{\text {th }}$ Defence, Security and Sensing Symposium, Apr. 16-22 2009, SPIE Proceedings, Orlando, Florida, USA, 2009.

[15] Obhođaš J., Valković V., Sudac D., Matika D., Pavić I., Kollar R.: Environmental Security of the Coastal Sea Floor in the Sea
Ports and Waterways of the Mediterranean Region, Nuclear instruments \& methods in physics research. Section A : Accelerators, spectrometers, detectors and associated equipment, 619 (2010), 1/3; pp. 419-426.

[16] Pavić I.: "The general model of mapping dangerous entity in maritime environment", Doctoral thesis, Faculty of Maritime Studies Rijeka, 2008.

[17] Valković V., Matika, D., Kollar R., Obhođaš J., Sudac D.: Environmental security of the Adriatic coastal sea floor, IEEE Transactions on Nuclear Science, 57(2010) 5, pp. 2724-2731.

[18] Valković V., Sudac D., Obhođaš J., Matika D., Kollar R., Nađ K. Orlić Z.: Inspection of Objects on the Sea Floor Utilizing 14 MeV Tagged Neutrons, Nuclear Science, IEEE Transactions on Nuclear Science 59(4), 2012, pp. 1237-1244.

[19] Valković V., Sudac D., Matika D.: Fast neutron sensor for detection of explosives and chemical warfare agents, Applied Radiation and Isotopes 68(2010) , 4/5, pp. 888-892.

[20] Valkovic V., Sudac D., Nađ K., Obhodas J., Matika D., Kollar R.: "Surveyor: An underwater system for threat material detection", Use of Nuclear and Non-nuclear Techniques for Humanitarian Demining and Explosives Detection. Proceedings of an IAEA Technical Meeting, http://www-pub.iaea. org/MTCD/Publications/PDF/P1441_CD/Papers2007/ valkovic.pdf.

[21] Vrbancich, J., Boyd, G., Mathews, K.: SeaTEM - A New Airborne Electromagnetic System for Bathymetric Mapping and Seafloor Characterization, EGM 2007 International Workshop Innovation in EM, Grav and Mag Methods: A new Perspective for Exploration, Capri, Italy, April 15 - 18, 2007.

[22] Vukić Z:: "Laboratory for Underwater systems and Technologies", https://www.fer.unizg.hr/zari/labust.

[23] Vukić Z.: "State and Perspective of Underwater Robotics", $10^{\text {th }}$ IFAC Conference on Control Applications in Marine Systems, Trondheim, Norway, 2016, http://www. ifac-cams2016.com/zoran-vukic.html.

[24] Zhang, L. P., Hong, H., et al.: Marine Environmental Security: An Evolving Concept, International Society for Environmental Information Sciences, Environmental Informatics Archives, Regina, Saskatchewan, Canada, Vol. 3, 2005.

[25] Zhongwei, D., Minhe, J., Zhihua Z.: Mapping Bathymetry From Multi-Source Remote Sensing Images: A Case Study In The Beilun Estuary, Guangxi, China The International Archives of the Photogrammetry, Remote Sensing and Spatial Information Sciences, Vol. XXXVII, Part B8, Beijing, 2008. 